\title{
Pallavi Rastogi, Afrindian Fictions: Diaspora, Race and National Desire in South Africa
}

\section{Elleke Boehmer}

\section{(2) OpenEdition \\ 1 Journals}

Electronic version

URL: https://journals.openedition.org/ces/8332

DOI: $10.4000 /$ ces.8332

ISSN: 2534-6695

\section{Publisher}

SEPC (Société d'études des pays du Commonwealth)

\section{Printed version}

Date of publication: 1 September 2010

Number of pages: 117-118

ISSN: 2270-0633

\section{Electronic reference}

Elleke Boehmer, "Pallavi Rastogi, Afrindian Fictions: Diaspora, Race and National Desire in South Africa", Commonwealth Essays and Studies [Online], 33.1 | 2010, Online since 11 December 2021, connection on 20 January 2022. URL: http://journals.openedition.org/ces/8332 ; DOI: https://doi.org/10.4000/ces. 8332

This text was automatically generated on 20 January 2022.

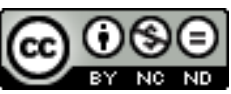

Commonwealth Essays and Studies is licensed under a Licence Creative Commons Attribution - Pas d'Utilisation Commerciale - Pas de Modification 4.0 International. 


\title{
Pallavi Rastogi, Afrindian Fictions: Diaspora, Race and National Desire in South Africa
}

\author{
Elleke Boehmer
}

\section{REFERENCES}

Pallavi Rastogi. Afrindian Fictions: Diaspora, Race and National Desire in South Africa.

Columbus: Ohio UP, 2008. 290 pp. ISBN 13 978-0-8142-0319-4

1 An articulate study of the South African Indian fiction that grew up during and after apartheid, Afrindian Fictions makes a welcome addition to at least two critical fields, South African literary criticism and the far-flung discourses of the South Asian diaspora. As Rastogi justly writes in her Introduction, the South African Indian community, and hence also its literature, forged in the crucible of the apartheid struggle, has tended to define itself as strongly according to its national affiliations to South Africa as to the transnational genealogies connecting back to India which tend to be more prominent in other Indian migrant communities. In South Africa, the eastwest patterns of contact that inform South Asian diaspora studies are more accurately described as east-south, going against prevailing interpretative trends. The result is a body of writing that legitimately invites the new coinage: Afrindian.

Paradoxically, despite the militant identity assertions of 1970s Black Consciousness, the Indian community's nationalist gestures of belonging to South Africa have not tended to translate into ready social or critical acceptance by other black communities within the country. So, as Rastogi explores in her six-chapter discussion, first of Afrindian short story writers, then of Ahmed Essop, Achmat Dangor, Farida Karodia, Praba Moodley and Imraan Coovadia, South African Indian fiction still makes up an isolated and neglected constituency. Yet it is one that amply repays closer study, interrogating as it does two dominant dichotomizing trends: the black-versus-white divisions of 
apartheid and anti-apartheid discourse; and the east-west, sometimes us-them, binary by which South Asian migration is generally understood. Against this polarization, Rastogi's efforts are two-pronged: she seeks to track an 'Africanization of Indian selfhood' in the writers' work, and to observe thereby the 'Indianization of South Africa.' At both levels, she is interested in mixings between Indian and African communities and in the hybridizing effects of these processes - a hybridity that is in many ways more entrenched and knotted than that enshrined in postcolonial theory. While references to key postcolonial commentators on the nation pepper the discussion throughout (with subaltern names, however, notable by their omission), her overarching aim is to challenge dominant meta-narratives in postcolonial studies, including, implicitly, the biculturalism that has organised discourses of migration, and of race and racial oppression. A "value-added" aspect to the book is the six appended interviews with prominent South African Indian cultural commentators, including some of the book's subjects.

3 Rastogi's attention to a lively literary area woefully neglected in many standard South African literary histories (Chapman, Sheckels) undoubtedly makes for a welcome addition to postcolonial migration studies, at a time when exciting research ventures are emerging in the fluid cultural economies of the African-Indian Ocean (Isabel Hofmeyr, Stephen Muecke, Stephanie Jones, and others). With its close readings of post-1980 writing, Afrindian Fictions traces the literary-historical trajectory of an important minority player on the South African national cultural stage, though the absence of any discussion of Achmat Dangor's disillusioned yet hopeful Bitter Fruit (2003) exploring the TRC aftermath, militant Islam, and the complex dimensions of cross-racial desire, is puzzling, as is the neglect of cultural landscapes other than those of Durban (dear as these are to this writer).

of course, it is a widely acknowledged if ironic truth that studies which investigate gaps in a field of knowledge also highlight by force of contrast their moments of inattention to adjacent gaps-of-field. Considering how revealing Rastogi is on the subject of postapartheid racial tensions between Indians and Africans, it would have been interesting to see her develop the difficult question of brown-on-black, and black-on-brown racism, one which has placed under pressure the cross-racial solidarity that mobilized radical groups during apartheid. Where Africanization is increasingly defined in essentialist terms, the class differences separating middle-class brown and poorer black may now provide the new laager behind which minority communities like South African Indians retreat, as Rastogi is aware. Durban-born President of Greenpeace Kumi Naidoo's ideal of Indians indigenizing to Africa without sacrificing their historical heritage may, regrettably, become a thing of the past. In this situation, Indians' muchpraised tendency to privilege national over transnational ties could come to look like a neglect of cross-border affiliations not only back to India, but also within the East African littoral - affiliations that could potentially provide alternative modes of belonging. It is a neglect which this study of the South African Indian community alone provocatively reproduces. 


\section{AUTHORS}

\section{ELLEKE BOEHMER}

Elleke BOEHMER is internationally known for her research in international writing and postcolonial theory. She is the author of the world best-seller Colonial and Postcolonial Literature: Migrant Metaphors $(1995,2005)$, the monographs Empire, the National and the Postcolonial, 1890-1920 (2002) and Stories of Women (2005), and of the creative biography Nelson Mandela (2008). She has also published four novels, Screens again the Sky (short-listed David Higham Prize, 1990), An Immaculate Figure (1993), Bloodlines (short-listed Sanlam Prize, 2000), and Nile Baby (2008), a first collection of short stories, Sharmilla and Other Portraits, as well as short stories and memoir sketches. She has produced the edition of Robert Baden-Powell's Scouting for Boys (2004), and the OUP collection, Empire Writing (1998), co-edited J.M. Coetzee in Context and Theory and Terror and the Postcolonial (2009), and The Indian Postcolonial (co-edited with Rosinka Chaudhuri, 2010). Elleke Boehmer is the Professor of World Literature in English at the University of Oxford. 